\title{
THE GLYCEMIC RESPONSE TO ISOGLUCOGENIC QUANTITIES OF PROTEIN AND CARBOHYDRATE
}

\author{
By JEROME W. CONN AND L. H. NEWBURGH \\ (From the Department of Internal Medicine, Medical School, University of Michigan, \\ Ann Arbor)
}

(Received for publication June 26, 1936)

In past years several objections to the use of a diet high in protein for the diabetic patient have been forwarded. These have fallen into three main groups-first, that in some way protein exerted a specific action, the result of which was to interfere with the mechanism of sugar utilization $(1,2,3,4)$; secondly, that the specific dynamic effect of protein in increasing heat production was wasteful in terms of total energy expenditure and as such should be minimized $(1,4,5,6)$; and, thirdly, that protein constituted a large source of endogenous glucose and therefore should be carefully curtailed in the diabetic diet. The latter is the only one that has in any measure stood the test of time as far as practical diabetic management is concerned $(7,8,9)$. It is our purpose to show that it is an advantage to the diabetic to derive a large part of his total metabolic glucose from protein foods.

It is a fact that during the metabolism of protein there occurs a yield of glucose which approximates 50 per cent of the weight of the ingested protein $(10,11,12,13,14,15)$. Janney (16) working with isolated proteins found that the glucose liberated varied from 48 per cent to 80 per cent. It is reasonable to state that 50 per cent represents a good average figure in calculating diets in which the total intake of protein is made up of a mixture of many single proteins.

Since protein in the diet represents a large source of glucose, it was decided to compare the blood sugar levels and glycosuria produced by ingestion of equivalent amounts of glucose derived on the one hand from protein and on the other from glucose and carbohydrate foods. The studies were made on fifteen diabetic patients and three normal fourth year medical students. Each subject was maintained aglycosuric for at least two weeks before the study was begun.
METHOD

The blood sugar level in the postabsorptive state was determined. At this time glucose was absent from all of the urine specimens. A breakfast consisting of 2 grams of protein per kilogram of body weight was given. The source of protein was lean beef from which all visible fat had been removed. This was ground and fried as hamburger steaks, using a minimum of butter in this process. The beef under these conditions contained 5 to 6 per cent of fat and 20 to 22 per cent of protein.

The time taken for ingestion of the meat varied from seven to twenty minutes. Blood and urine specimens were collected hourly for eight hours. Timing was begun immediately after the conclusion of breakfast.

Blood sugar was determined by the Benedict (17) method and blood urea nitrogen by the Van Slyke (18) urease method. Urinary sugar was determined by the Benedict (19) method and urinary nitrogen by the Kjeldahl method.

On another day a similar procedure was followed, but this time the breakfast consisted of one gram of carbohydrate per kilogram of body weight. This meal was given as glucose or as carbohydrate food calculated to yield this amount of glucose. When carbohydrate was used, specimens were collected for from three to four hours. In several subjects the response to various carbohydrate foods yielding equivalent amounts of glucose was compared with that obtained when the glucose was derived from protein. It is assumed that protein yields, during metabolism, glucose equal to 50 per cent of its weight.

\section{RESULTS}

Figures 1 and 2 represent the results obtained from the normal group, showing that the response to ingestion of glucose is the expected one with 

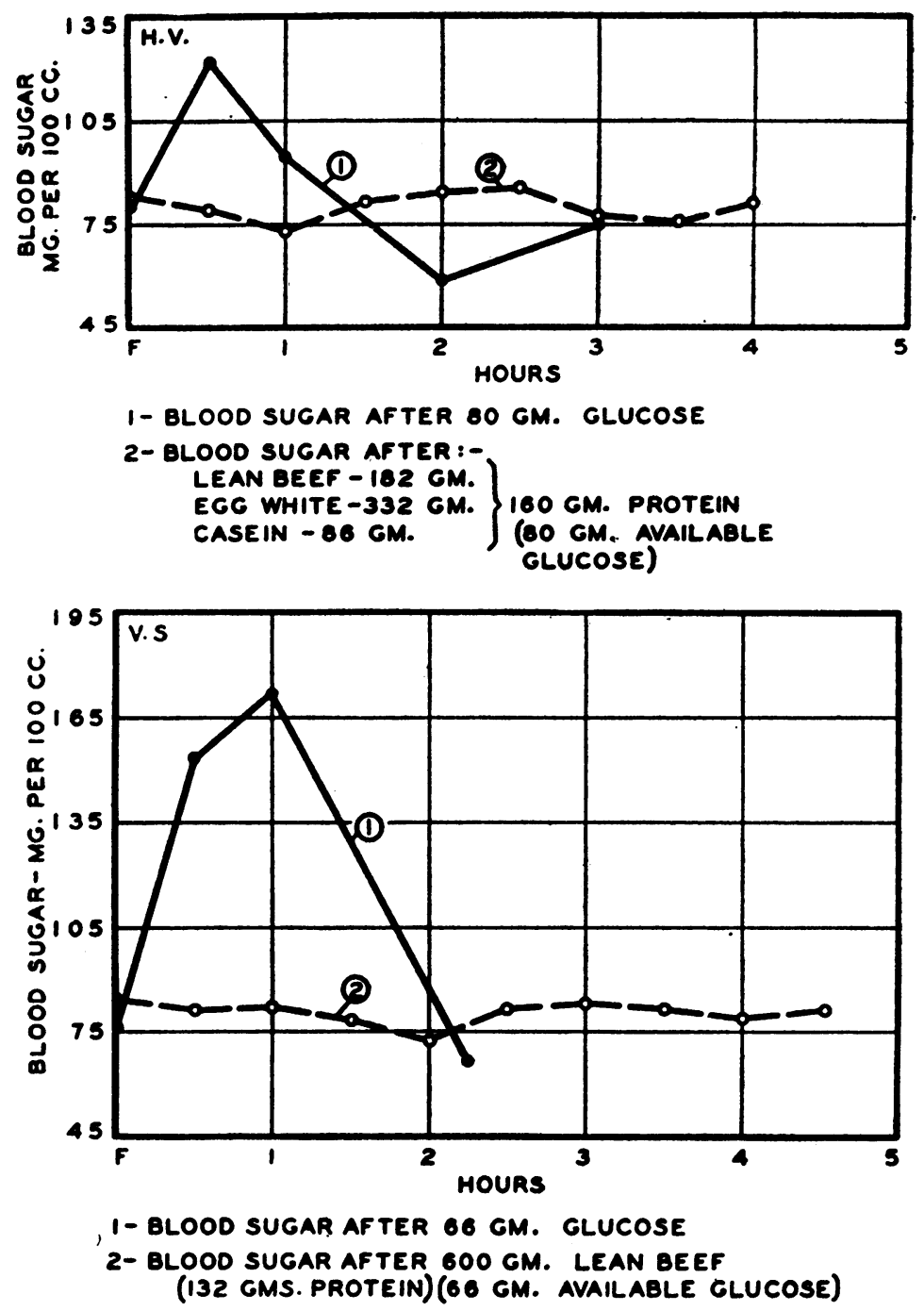

Fig. 1. Blood Sugar Curves in Normal Subjects, V. S. and H. V.

the usual variation. When an equivalent amount of glucose is derived from protein, however, the blood sugar curve remains flat. The rising blood urea nitrogen in Figure 2 indicates that protein is being metabolized. During the same period the blood sugar does not rise significantly.

Figures 3 and 4 show the results obtained in two diabetic subjects. A diabetic response to the ingestion of glucose is obtained. The curves after protein ingestion, however, remain essentially flat for an 8 hour period. Again, the rising blood urea nitrogen indicates protein utilization. The other curves show the values obtained after ingestion of equivalent amounts of glucose de- rived from various carbohydrate foods. These curves resemble to a large degree those obtained after glucose ingestion.

This confirms the recent observations of Wishnofsky and Kane (20) on the effect of equivalent amounts of dextrose and starch on glycemia and glycosuria. A marked glycosuria was found, in our studies, after ingestion of glucose or carbohydrate, while there was none after the protein meal.

Table I presents in quantitative terms the glycosuria found during the experimental period illustrated by Figure 4 . When glucose or soluble starch was fed, approximately one-third of the 


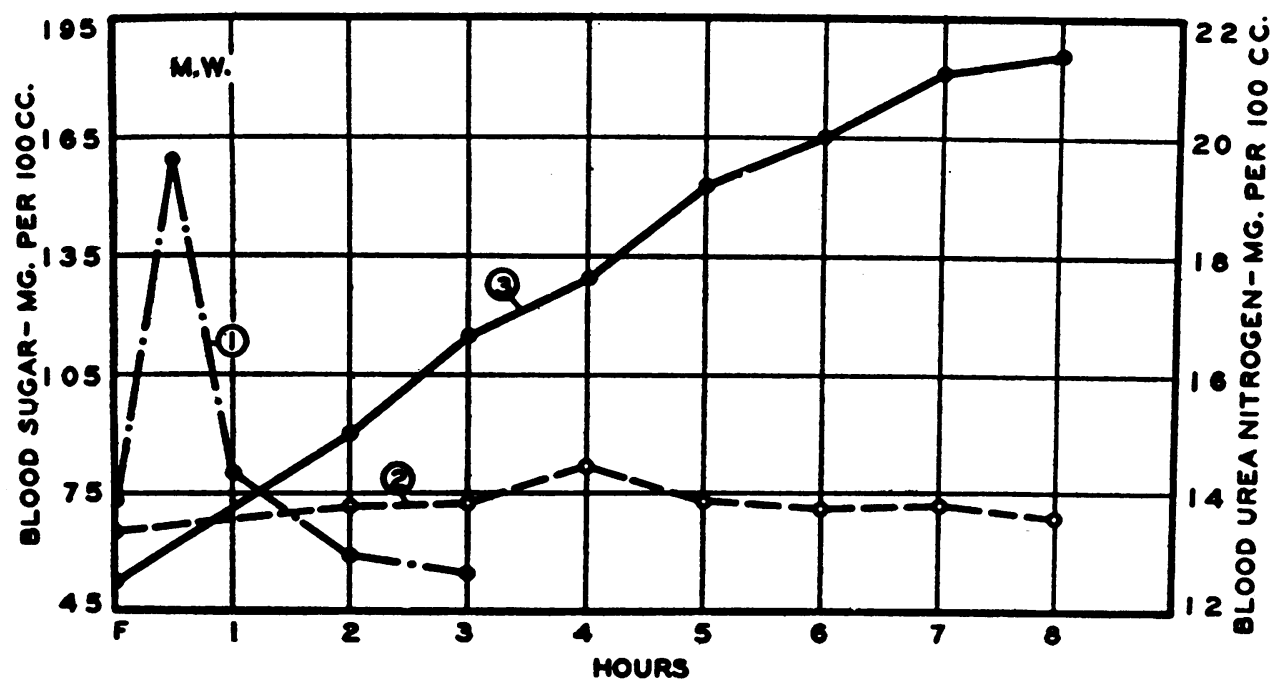

1- BLOOO SUGAR AFTER 66 GM. GLUCOSE

2- BLOOD SUGAR AFTER $600 \mathrm{GM}$. LEAN BEEF (132 GM. PROTEIN)

(66 GM. MAIL ABLE GLUCOSE)

3- BLOOD UREA NITROGEN AFTEA $600 \mathrm{GM}$. LEAN BEEF

(132 GM. PROTEIN)

Fig. 2. Blood Sugar and Blood Urea Nitrogen in Normal Subject M. W.

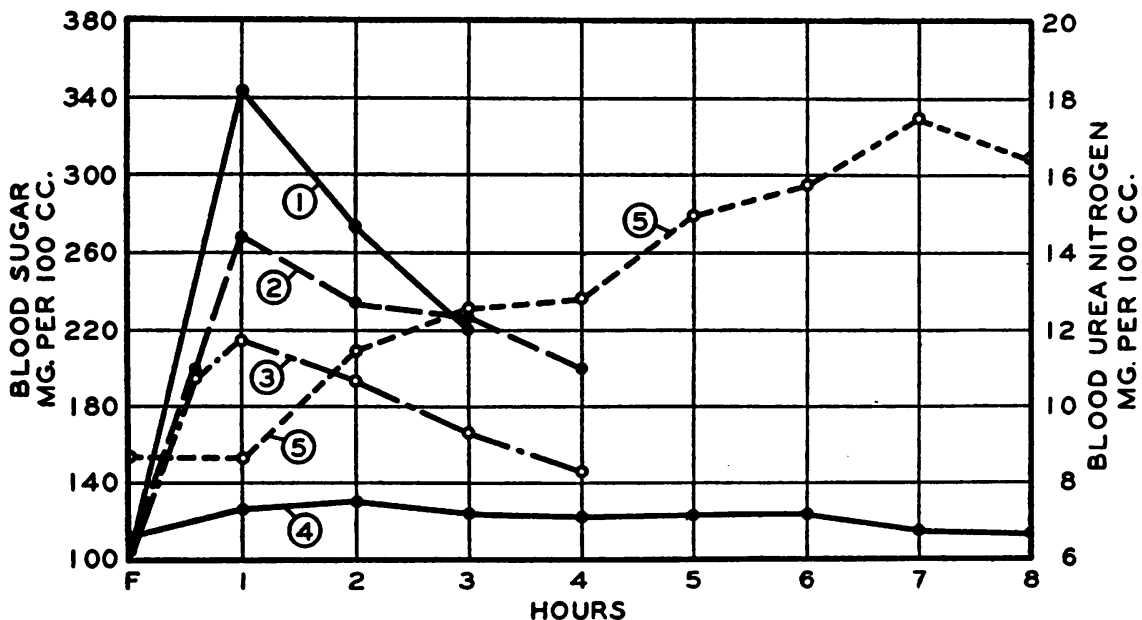

(1)-BLOOD SUgaR AFTER 53 GMS. GLUCOSE

(2) -BLOOD SUGAR AFTER 100 GMS. BREAD \& 25 GMS. BUTTER

(53 GMS. AVAILABLE GLUCOSE)

(3) - BLOOD SUGAR AFTER 370 GMS. APPLE (53 GMS. AVAILABLE GLUCOSE)

(4)-BLOOD SUGAR AFTER 485 GMS. LEAN BEEF (106 GMS. PROTEIN)

(53 GMS. AVAILABLE GLUCOSE)

(5) - BLOOD UREA NITROGEN AFTER 485 GMS. LEAN BEEF (106 GMS.PROTEIN)

Fig. 3. Blood Sugar and Blood Urea Nitrogen in Case II 


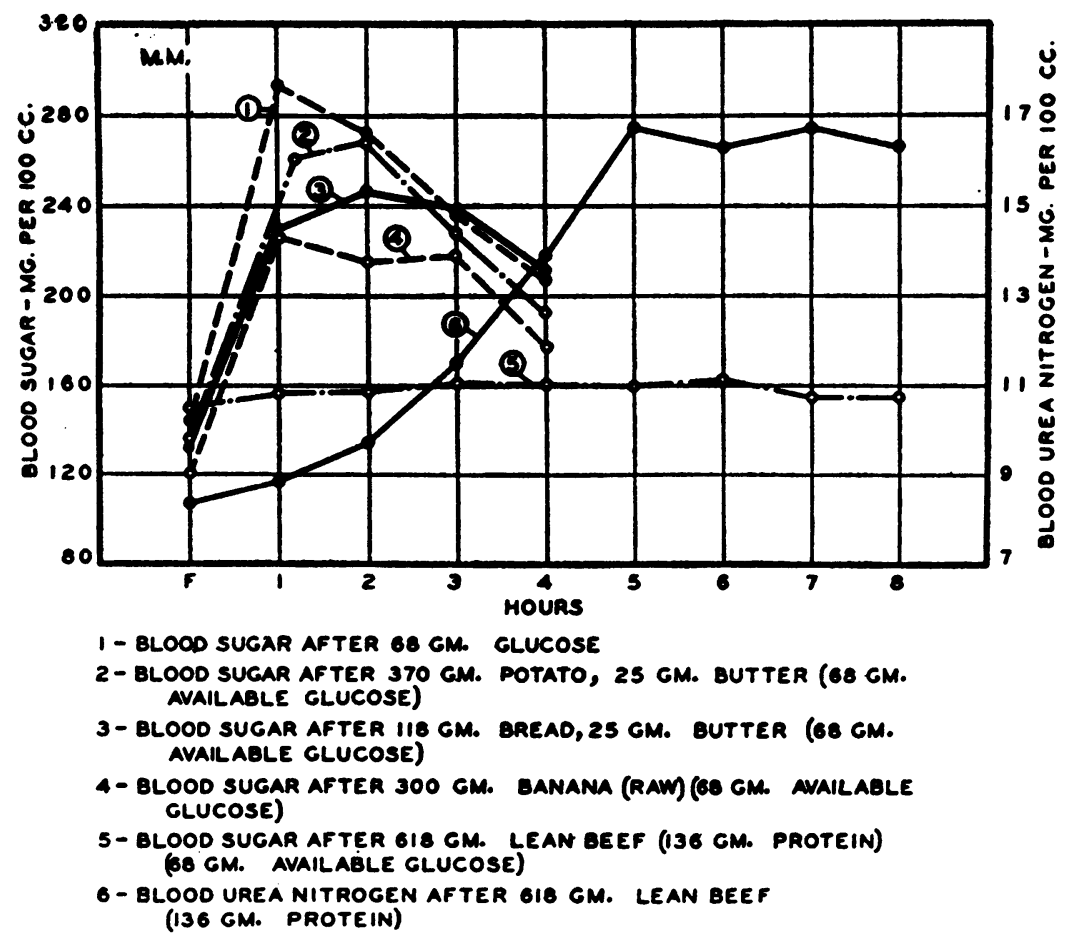

Fig. 4. Blood Sugar and Blood Urea Nitrogen in Case I

ingested glucose appeared in the urine in 4 hours. In the case of raw starch (raw fruits) a lesser amount of glycosuria appeared in the four hour period. During the entire 8 hour period following ingestion of 617 grams of lean beef, however, there was no glycosuria.

Detailed data of these and the other subjects studied are seen in Table II. The average maximal increase in blood sugar above the fasting level after ingestion of carbohydrate was 160

TABLE I

Glycosuria of various foods in diet of Case I (M. M.)

\begin{tabular}{|c|c|c|c|c|}
\hline$\underset{\text { ingested }}{\text { Food }}$ & Amount & $\begin{array}{c}\text { Available } \\
\text { glucose }\end{array}$ & \multicolumn{2}{|c|}{$\begin{array}{l}\text { Urinary glucose } \\
\text { (first } 4 \text { hours) }\end{array}$} \\
\hline & grams & grams & grams & $\begin{array}{c}\text { per cent of } \\
\text { ingested glucose }\end{array}$ \\
\hline Lean beef & 617 & 68 & $0 *$ & $0_{*}^{*}$ \\
\hline $\begin{array}{l}\text { Orange juice } \\
\text { Dextrose }\end{array}$ & $\left.\begin{array}{r}200 \\
47\end{array}\right\}$ & 68 & 23.0 & 33.8 \\
\hline $\begin{array}{l}\text { Potato (steamed) } \\
\text { Butter }\end{array}$ & $\left.\begin{array}{r}370 \\
25\end{array}\right\}$ & 68 & 22.5 & 33.0 \\
\hline $\begin{array}{l}\text { Bread } \\
\text { Butter }\end{array}$ & $\left.\begin{array}{r}118 \\
25\end{array}\right\}$ & 68 & 23.3 & 34.2 \\
\hline Banana, raw & 300 & 68 & 11.2 & 16.4 \\
\hline
\end{tabular}

${ }^{*}$ No urinary glucose during entire 8 hour experimental period. mgm. per $100 \mathrm{cc}$. of blood and was invariably attended by glycosuria. When an equivalent amount of glucose was derived from protein the average maximal increase was $37 \mathrm{mgm}$. per 100 cc., and little or no glycosuria resulted. It is noteworthy, too, that the small increase in blood sugar after protein feeding appears to parallel the severity of the disease much more closely than does the rise after the ingestion of glucose.

\section{DISCUSSION}

These studies demonstrate that ingested protein causes a very much smaller increase in the blood sugar than results from an equivalent amount of glucose or carbohydrate food. We believe that the explanation involves a principle which has received very little attention.

We are accustomed to measure the capacity of a diabetic to dispose of glucose in terms of the total number of grams of glucose released from his diet in 24 hours. The number of grams of glucose that just fails to produce glycosuria is taken to be a measure of the largest amount of glucose that the patient can utilize in a 24 hour period. This conception takes no account of the 
rate at which the total amount of glucose produced in 24 hours enters the blood stream. Since maximal tolerance without glycosuria depends upon the rate at which the body is able to remove glucose from the blood stream by oxidation, deposition as glycogen, and transformation to fat, the time element assumes an importance at least equal to that of total yield of glucose in grams.

Doyon and Dufourt (21) in 1901 first noted that the rate of injection of glucose into the blood stream was a very important factor in the production of glycosuria. They found that a much greater quantity of glucose could be given per unit of time without causing glycosuria if the rate of injection was slow. Blumenthal (22) in 1905 did an interesting experiment bearing on the influence of the time element upon the production of glycosuria. $\mathrm{He}$ ascertained the dose of glucose that could be given intravenously every fifteen minutes without producing glycosuria. A dose slightly in excess of this always produced glycosuria. After having found the maximal dose that failed to produce glycosuria when given every fifteen minutes, he then gave one of

TABLE II

Data from all of the subjects studied

\begin{tabular}{|c|c|c|c|c|c|c|c|c|c|c|c|c|c|}
\hline \multirow{2}{*}{$\begin{array}{c}\text { Case } \\
\text { number }\end{array}$} & \multirow{2}{*}{ Weight } & \multirow{2}{*}{ Age } & \multirow{2}{*}{$\begin{array}{c}\text { Tolerance * } \\
\text { (available } \\
\text { glucose) }\end{array}$} & \multicolumn{4}{|c|}{ Food ingested } & \multicolumn{2}{|c|}{ Blood sugar } & \multirow{2}{*}{ Glycosuria † } & \multirow{2}{*}{$\begin{array}{l}\text { Maxi- } \\
\text { mal in- } \\
\text { crease } \\
\text { in } \\
\text { blood } \\
\text { urea } \\
\text { nitro- } \\
\text { gen }\end{array}$} & \multicolumn{2}{|c|}{$\begin{array}{c}\text { Urinary } \\
\text { nitrogen } \\
\text { (8 hour period) }\end{array}$} \\
\hline & & & & Type & Amount & $\begin{array}{l}\text { Pro- } \\
\text { tein }\end{array}$ & $\begin{array}{l}\text { able } \\
\text { glucose }\end{array}$ & Fasting & mal in- & & & $\begin{array}{c}\text { Fast- } \\
\text { ing }\end{array}$ & $\underset{\text { test }}{\text { During }}$ \\
\hline & kgm. & years & grams & & grams & grams & grams & $\begin{array}{c}\text { mgm. } \\
\text { per } \\
100 \mathrm{cc} .\end{array}$ & $\begin{array}{c}\text { mgm. } \\
\text { per } \\
100 \mathrm{cc} .\end{array}$ & grams & $\begin{array}{c}\text { mgm. } \\
\text { per } \\
100 \mathrm{cc} .\end{array}$ & grams & grams \\
\hline
\end{tabular}

* Tolerance here is meant to represent the maximal number of grams of available glucose that the diabetic can utilize without glycosuria in a 24 hour period without the aid of exogenous insulin when he is given the usual three diabetic meals a day. (The usual diabetic diet contains about two-thirds of a gram of protein per kilo per day). This implies the absence of infection or other complication known to lower tolerance.

+ During the protein test the presence or absence of glycosuria was followed for the entire 8 hour experimental period. After glucose or carbohydrate foods this was followed for only four hours and many subjects continued to have marked glycosuria after four hours. 
TABLE II-Continued

\begin{tabular}{|c|c|c|c|c|c|c|c|c|c|c|c|c|c|c|}
\hline \multirow{3}{*}{$\begin{array}{c}\text { Case } \\
\text { number }\end{array}$} & \multirow{3}{*}{ Weight } & \multirow{3}{*}{ Age } & \multirow{3}{*}{$\mid \begin{array}{c}\text { Tolerance * } \\
\text { (available } \\
\text { glucose) }\end{array}$} & \multicolumn{4}{|c|}{ Food ingested } & \multicolumn{2}{|c|}{ Blood sugar } & \multirow{3}{*}{\multicolumn{2}{|c|}{ Glycosuria $†$}} & \multirow{4}{*}{$\begin{array}{c}\text { Maxi- } \\
\text { malin- } \\
\text { crease } \\
\text { in } \\
\text { blood } \\
\text { urea } \\
\text { nitro- } \\
\text { gen } \\
\text { mgm. } \\
\text { per } \\
100 \text { cc. } \\
9.3\end{array}$} & \multirow{2}{*}{\multicolumn{2}{|c|}{$\begin{array}{c}\text { Urinary } \\
\text { nitrogen } \\
\text { (8 hour period) }\end{array}$}} \\
\hline & & & & \multirow{2}{*}{ Type } & \multirow{2}{*}{ Amount } & \multirow{2}{*}{$\begin{array}{l}\text { Pro- } \\
\text { tein }\end{array}$} & \multirow{2}{*}{$\begin{array}{c}\text { Avail- } \\
\text { able } \\
\text { glucose }\end{array}$} & \multirow{2}{*}{ Fasting } & \multirow{2}{*}{$\begin{array}{l}\text { Maxi- } \\
\text { mal in- } \\
\text { crease }\end{array}$} & & & & & \\
\hline & & & & & & & & & & & & & $\begin{array}{c}\text { Fast- } \\
\text { ing }\end{array}$ & $\begin{array}{c}\text { During } \\
\text { test }\end{array}$ \\
\hline $\mathbf{x}$ & $\begin{array}{c}\text { kgm. } \\
72\end{array}$ & $\begin{array}{c}\text { years } \\
47\end{array}$ & $\begin{array}{c}\text { grams } \\
80\end{array}$ & $\begin{array}{l}\text { Lean beef } \\
\text { Dextrose } \\
\text { Bread } \\
\text { Butter }\end{array}$ & $\left.\begin{array}{c}\text { grams } \\
654 \\
72 \\
124 \\
125\end{array}\right\}$ & $\begin{array}{l}\text { grams } \\
144\end{array}$ & $\begin{array}{c}\text { grams } \\
72 \\
72 \\
72\end{array}$ & $\begin{array}{c}\text { mgm. } \\
\text { per } \\
100 \text { cc. } \\
90 \\
89 \\
66\end{array}$ & $\begin{array}{c}\text { mgm. } \\
\text { per } \\
100 c c . \\
64 \\
208 \\
211\end{array}$ & $\begin{array}{l}++ \\
++t \\
++t+\end{array}$ & $\begin{array}{c}\text { grams } \\
4.1 \\
20.0 \\
10.8\end{array}$ & & $\begin{array}{c}\text { grams } \\
2.7\end{array}$ & $\begin{array}{c}\text { grams } \\
11.4\end{array}$ \\
\hline $\mathbf{X I}$ & 66 & 32 & 80 & $\begin{array}{l}\text { Lean beef } \\
\text { Dextrose }\end{array}$ & $\begin{array}{r}610 \\
66 \\
\end{array}$ & 132 & $\begin{array}{l}66 \\
66 \\
\end{array}$ & $\begin{array}{l}101 \\
115\end{array}$ & $\begin{array}{r}75 \\
163\end{array}$ & $++_{+}^{+}$ & & 7.5 & & \\
\hline XII & 72 & 29 & $\begin{array}{l}\text { o (Total } \\
\text { diabetic) }\end{array}$ & $\begin{array}{l}\text { Lean beef } \\
\text { Dextrose }\end{array}$ & $\begin{array}{r}615 \\
67\end{array}$ & 135 & $\begin{array}{l}67.5 \\
67\end{array}$ & $\begin{array}{l}125 \\
166\end{array}$ & $\begin{array}{l}170 \\
174\end{array}$ & $+t+t$ & & 11.3 & 3.4 & 7.3 \\
\hline XIII & 62 & 49 & $?$ & $\begin{array}{l}\text { Lean beef } \\
\text { Dextrose }\end{array}$ & $\begin{array}{r}560 \\
62\end{array}$ & 124 & $\begin{array}{l}62 \\
62\end{array}$ & $\begin{array}{l}128 \\
142\end{array}$ & $\begin{array}{r}34 \\
138\end{array}$ & $\stackrel{0}{++t+}$ & 9.4 & & 3.2 & 5.9 \\
\hline XIV & 28 & 10 & 65 & $\begin{array}{l}\text { Lean beef } \\
\text { Dextrose }\end{array}$ & 254 & 56 & $\begin{array}{r}28 \\
\text { done }\end{array}$ & 120 & 56 & Tr. & 0.4 & 9.3 & 2.5 & 5.8 \\
\hline $\mathbf{X V}$ & 56 & 16 & $?$ & $\begin{array}{l}\text { Lean beef } \\
\text { Dextrose }\end{array}$ & $\begin{array}{r}509 \\
56\end{array}$ & 112 & $\begin{array}{l}56 \\
56\end{array}$ & $\begin{array}{r}128 \\
81\end{array}$ & $\begin{array}{r}9 \\
141\end{array}$ & $\stackrel{0}{++t}$ & 4.8 & & 4.1 & 8.6 \\
\hline
\end{tabular}

NORMALS

\begin{tabular}{|c|c|c|c|c|c|c|c|c|c|c|c|}
\hline H.V. & 73 & 23 & Normal & $\begin{array}{l}\text { Lean beef } \\
\text { Egg white } \\
\text { Casein } \\
\text { Dextrose }\end{array}$ & $\left.\begin{array}{r}182 \\
332 \\
86 \\
80\end{array}\right\}$ & 160 & $\begin{array}{l}80 \\
80\end{array}$ & $\begin{array}{l}83 \\
80\end{array}$ & $\begin{array}{r}2 \\
42\end{array}$ & $\begin{array}{l}0 \\
0\end{array}$ & \\
\hline V.S. & 75 & 24 & Normal & $\begin{array}{l}\text { Lean beef } \\
\text { Dextrose }\end{array}$ & $\begin{array}{r}600 \\
66\end{array}$ & 132 & $\begin{array}{l}66 \\
66\end{array}$ & $\begin{array}{l}84 \\
76\end{array}$ & $\begin{array}{l}-1 \\
97\end{array}$ & $\begin{array}{l}0 \\
+\end{array}$ & \\
\hline M.W. & 71 & 24 & Normal & $\begin{array}{l}\text { Lean beef } \\
\text { Dextrose }\end{array}$ & $\begin{array}{r}600 \\
66\end{array}$ & 132 & $\begin{array}{l}66 \\
66\end{array}$ & $\begin{array}{l}66 \\
74\end{array}$ & $\begin{array}{l}16 \\
82\end{array}$ & $\stackrel{0}{+}$ & 8.9 \\
\hline
\end{tabular}

the series of injections 10 minutes after the preceding one. This provoked glycosuria. The next injection at the regular time in the series failed to produce glycosuria. The crest of the glycemic wave produced by the irregular injection was higher than those which followed the regularly timed injections (every 15 minutes). The renal threshold was thus exceeded even though the total amount of glucose for the whole period was the same. Woodyatt et al. (23) in 1915 made the incisive statement, "Tolerance must be regarded as a velocity, not as a weight. It must be measured and expressed in grams of glucose per kilogram of body weight per hour of time or in other convenient units of weight and time."

It is not surprising, then, that the diabetic, whose capacity to utilize glucose is already damaged, when given his total 24 hour quantity of glucose in the form of three meals over a 10 hour period, has excessive hyperglycemia and glycosuria. Yet his true capacity for disposing of glucose in 24 hours may not have been exceeded. In 1922
Gray (24) reported better results in diabetics when the total quantity of food was divided into six meals than when three meals were given. This could easily be explained on the time factor alone.

In the process of protein metabolism, the complex protein molecule is split in the intestinal tract to amino-acids. These are absorbed into the blood stream and transported to the liver where oxidative deamination occurs. Here the glycogenic amino-acids are split to form urea and glucose. That this process is a slow one is shown in the charts by the slowly rising blood urea nitrogen. Glucose is, therefore, liberated into the blood stream in this process at a slow and even rate over a prolonged period of time. Under these conditions the diabetic is able to utilize a greater total amount of glucose without glycosuria in the eight hour period. Therefore, the inability of a diabetic to dispose of large quantities of glucose is partially compensated if the glucose is presented for utilization slowly and evenly. There appears, 
then, to be some advantage to the diabetic of this slow liberation of glucose from protein foods. ${ }^{1}$

\section{CONCLUSIONS}

(1) A comparison was made between the glycemic and glycosuric responses after ingestion of equivalent amounts of glucose derived from glucose per se, protein and carbohydrate foods in normals and in diabetics.

(2) Within the limits of these studies there is a decided advantage to the diabetic of deriving glucose from protein.

(3) The slow rate of liberation of glucose into the blood stream during protein metabolism is the explanation of the results obtained.

\section{BIBLIOGRAPHY}

1. Wilder, R. M., Boothby, W. M., and Beeler, C., Studies of the metabolism of diabetes. J. Biol. Chem., 1922, 51, 311.

2. Petrén, K., Studies on diabetes. J. Metabolic Research, 1925, 5, 7.

3. Petrén, $\mathrm{K}$., Etudes sur la question de "N-minimum" chez les diabetiques. Acta med. Scandinav., 1922, Supp. 3, 101.

4. Lusk, G., The Elements of the Science of Nutrition. W. B. Saunders Co., Philadelphia, 1928, 4th ed.

5. Bartlett, W. M., Protein requirement as determined in diabetic children. Am. J. Dis. Child., 1926, 32, 641.

6. Lyall, A., On the effect of protein in the diet of patients suffering from diabetes mellitus. Quart. J. Med., 1927, 20, 115.

7. Wang, C. C., Hawks, J. E., Huddlestun, B., Wood, A. A., and Smith, E. A., Influence of high and low protein diet on the basal metabolism and the chemistry of blood and urine in normal women. J. Nutrition, 1930, 3, 79.

8. Thannhauser, S. J., and Markowicz, W., Uber die Einwirkung des eiweisses auf die Ketonkörperausscheidung beim schweren diabetes mit bemerkungen zur Theorie die diabetischen störung. Klin. Wchnschr., 1925, 4, 2093.

${ }^{1}$ Studies are now being conducted with prolonged feeding of high protein diets to diabetics to determine the therapeutic significance of these observations.
9. Lieb, C. W., The effects of an exclusive long continued meat diet. J. A. M. A., 1926, 87, 25.

10. Minkowski, O., Untersuchungen über den Diabetes mellitus nach Exstirpation des Pankreas. Arch. f. exper. Path. u. Pharmakol., 1893, 31, 85.

11. Reilly, F. H., Nolan, F. W., and Lusk, G., Phlorizin diabetes in dogs. Am. J. Physiol., 1898, 1, 395.

12. Mandel, A. R., and Lusk, G., Stoff wechselbeobachtungen an einem Falle von Diabetes mellitus, mit besonderer Berücksichtigung der Prognose. Deutsches Arch. f. klin. Med., 1904, 81, 472.

13. Ringer, A. J., and Lusk, G., Uber die Entstehung von Dextrose aus Aminosäuren bei Phlorhizinglykosurie. Ztschr. f. physiol. Chem., 1910, 66, 106.

14. Janney, N. W., and Csonka, F. A., The metabolic relationship of the proteins to glucose. II. Glucose formation from body proteins. J. Biol. Chem., 1915, 22, 203.

15. Janney, N. W., The metabolic relationship of the proteins to glucose. J. Biol. Chem., 1915, 20, 321.

16. Janney, N. W., Glucose formation from protein in diabetes. Arch. Int. Med., 1916, $18,584$.

17. Benedict, S. R., The analysis of whole blood. II. The determination of sugar and of saccharoids (non-fermentable, copper-reducing substances). J. Biol. Chem., 1931, 92, 141.

18. Peters, J. P., and Van Slyke, D. D., Quantitative Clinical Chemistry. Volume II. Methods. Williams and Wilkins Co., Baltimore, 1932, p. 558.

19. Benedict, S. R., The detection and estimation of glucose in urine. J. A. M. A., 1911, 57, 1193.

20. Wishnofsky, M., and Kane, A. P., The effect of equivalent amounts of dextrose and starch on glycemia and glycosuria in diabetics. Am. J. M. Sc., 1935, 189, 545.

21. Doyon, M., and Dufourt, E., Sur Les Conditions Expérimentales de la Consommation Tissulaire du Glucose Injecté Dans les Veines. J. de physiol. et de path. gén., 1901, 3, 703.

22. Blumenthal, F., Zur Lehre von der Assimilationsgrenze de Zuckerarten. Beitr. z. chem. Physiol. u. Path., 1905, 6, 329.

23. Woodyatt, R. T., Sansum, W. D., Wilder, R. M., Prolonged and accurately timed intravenous injec-

- tions of sugar. A preliminary report. J. A. M. A., 1915, 65, 2067.

24. Gray, H., Divided meals for severe diabetics. Boston M. and S. J., 1922, 186, 763. 